\title{
Letter \\ Nucleus pulposus cells as competent phagocytes to clear apoptotic cells: mission applicable or impossible? Authors' response
}

\author{
Philip Jones ${ }^{1,2}$, Lucy Gardner ${ }^{1,2}$, Janis Menage ${ }^{1}$, Gwyn T Williams ${ }^{2}$ and Sally Roberts ${ }^{1,2}$ \\ ${ }^{1}$ Centre for Spinal Studies, Robert Jones \& Agnes Hunt Orthopaedic \& District Hospital NHS Trust, Oswestry, Shropshire SY10 7AG, UK \\ ${ }^{2}$ Institute of Science and Technology in Medicine, Keele University, Keele, Staffordshire ST5 5BG, UK
}

Corresponding author: Sally Roberts, Sally.Roberts@rjah.nhs.uk

Published: 6 May 2009

Arthritis Research \& Therapy 2009, 11:406 (doi:10.1186/ar2672)

This article is online at http://arthritis-research.com/content/11/3/406

(c) 2009 BioMed Central Ltd

See related research by Jones et al., http://arthritis-research.com/content/10/4/R86 and related letter by Wang and Luo, http://arthritis-research.com/content/11/3/405

We thank Dr Wang and Dr Luo for their interest in our paper demonstrating the ability of intervertebral disc cells to undergo phagocytosis [1], and we can certainly concur with some of the points they raise [2]. In fact, we addressed the first point in the last paragraph of the Discussion, stating that 'Although disc cells usually occur in isolation ...', disc cells do occur adjacent to each other in clusters of cells that are common in degenerate discs [1]. It is in this situation that we suggest our findings could have relevance in vivo in humans.

We would suggest that the second point made by Wang and Luo has very little bearing on our study. In intact adult discs there is little evidence of T cells being present, and therefore this comment is of limited relevance.

Wang and Luo's third point is certainly true and pertinent to all cell culture studies - the results of which can only be interpreted, bearing in mind all the limitations of making any deductions from in vitro studies to an in vivo situation.

The objective of the study was to determine whether disc cells could undergo phagocytosis [1], a property that as far as we were aware had not previously been demonstrated. To this effect we believe our study produced novel findings and provides the foundation for further work defining the contribution of phagocytosis of apoptotic cells under both physiological and pathological conditions.

\section{Competing interests}

The authors declare that they have no competing interests.

\section{References}

1. Jones P, Gardner L, Menage J, Williams GT, Roberts S: Intervertebral disc cells as competent phagocytes in vitro: implications for cell death in disc degeneration. Arthritis Res Ther 2008, 10:R86.
2. Wang H-Q, Luo Z-J: Nucleus pulposus cells as competent phagocytes to clear apoptotic cells: mission applicable or impossible? Arthritis Res Ther 2009, 11:405. 